\title{
Performance Parameters, Plasma Lipid Status, and Lymphoid Tissue Fatty Acid Profile of Broiler Chicks Fed Camelina Cake
} http://dx.doi.org/10.1590/1806-9061-2019-1053

\section{-Author(s)}

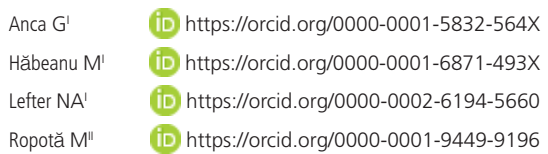

National Research \& Development Institute for Animal Biology and Nutrition, Laboratory of Animal Nutrition, Balotesti, Calea Bucuresti no.1, 077015, llfov, Romania.

National Research \& Development Institute for Animal Biology and Nutrition, Laboratory of Chemistry and Nutrition Physiology, Balotesti, Calea Bucuresti no.1, 077015, Ilfov, Romania.

\section{Mail Address}

Corresponding author e-mail address Gheorghe Anca

Laboratory of Animal Nutrition, National Research Development Institute for Animal Biology and Nutrition, 1 Calea Bucuresti, Balotesti, 077015, Iffov, Romania.

Phone: +40-021-3512081

Email: anca.gheorghe@ibna.ro

\section{aKeywords}

Broilers performance, camelina cake, immune organs, n-3 fatty acids, plasma lipid profile.

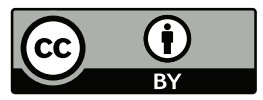

Submitted: 27/May/2019

Approved: 24/September/2019

\section{ABSTRACT}

The effects of dietary camelina cake (CAMC) on broiler chicks'growth performance, plasma lipid status and fatty acid profile (FA) of lymphoid organs were evaluated. Six hundred broilers (3-week-old, Cobb 500) were randomly allotted for 20 days in a feeding trials into 2 groups: control (C; corn-soybean meal-canola meal basal diet) and experimental (CAMC; $80 \mathrm{~g}$ CAMC/kg diet replaces canola meal from C diet). Blood samples ( $n=12$ /group) were collected on day 42 for plasma profile analysis (glucose, Glu; total cholesterol, TC; high-density lipoprotein cholesterol, HDL-C; low-density lipoprotein cholesterol, LDL-C; triglycerides) and immune organs (spleen, thymus, bursa of Fabricius) for FA analysis. The FA profile of lymphoid tissue was determined by gas chromatography. Feeding the CAMC diet did not influence broilers performance parameters or relative weights of lymphoid tissue, except the weight of bursa that decreased $(p<0.05)$. Plasma lipids profile was affected by decreasing $(p<0.05)$ the concentrations of Glu, TC, HDL-C and LDL-C in broilers fed the CAMC diet. In all lymphoid tissue, the total content of $n-3$ polyunsaturated fatty acids (PUFA) increased $(p<0.001)$ and the total level of $n-6$ PUFA decreased $(p<0.001)$ as the effect of the CAMC diet. The $n-6: n-3$ ratio decreased $(p<0.001)$ up to $5: 1$ in all lymphoid tissue. The higher $(p<0.05)$ concentration of arachidonic acid was found in the spleen, followed by the thymus and the bursa of the chicks fed the CAMC diet. Our results indicate that feeding $80 \mathrm{~g} /$ $\mathrm{kg}$ camelina cakes in broiler chicks finisher diet had no negative impact on productivity, beneficially alter the plasma lipid status and fatty acids profile of lymphoid tissue.

\section{INTRODUCTION}

Over the last years, there has been an increased interest to modulate the n-3 polyunsaturated fatty acids (PUFA) profile of poultry meat in order to improve its nutritional value and to increase the consumption of these fatty acidsby humansdue to healthier benefits (Rymer \& Givens, 2005; Wood et al., 2008; Poureslami et al., 2010; Ribeiro et al., 2013; Bhalerao et al., 2014; Nain et al., 2015).

Moreover, feeding n-3 PUFA enriched diets resulted in the deposition of these fatty acids into the lipid membrane of all tissues, including the cells of the immune system (Cinader et al., 1983; Huang \& Fritsche, 1992) and could affect the immune response and reduce inflammation in different species such as chicken, mice and fish (Babu et al., 2005; Puthpongsiriporn \& Scheideler, 2005; Calder, 2006; Wall et al., 2010). It is known that lymphoid tissues play an important role in the body defences against pathogens and its development can in some cases reflect immune system response and functionality (Grasman, 2002; Smith \& Hunt, 2004; Akter et al., 2006). In the 
chickens' central lymphoid organs are the thymus and the bursa of Fabricius, while peripheral lymphoid organs include the spleen and all the lymphoid tissue associated with the intestinal mucosa. The spleen is the major site of immune responses to blood-borne antigens and is also a site of hematopoiesis (Batista \& Harwood, 2009).

However, the potential to alter the nutrient composition of tissue strongly differs according to the feed ingredient considered. Recently, the development of the biofuels industry resulted in a significant increase of by-products (meals or cakes), vegetable sources rich in protein and energy which can be utilized in poultry diets.

Camelina oil cake (CAMC), a by-product of Camelina sativa (L. Crantz) oil seed plant, belonging to the Brassica family (Ghamkhar et al., 2010), has attained interest as a potential feed ingredient due to its high oil content (10 to $22 \%$ ) and favourable FA composition, especially thea-linolenic acid content (16.28 to 29\%; Cherian, 2012). The available scientific information on the effects of camelina oil cake or meal in broiler diets are conflicting regarding the production performance (Ryhanen et al., 2007; Frame et al., 2007; Pekel et al., 2009; Pekel et al., 2015), or limited on fatty acid composition of muscle tissues (Cherian et al., 2009; Aziza et al., 2010; Cherian, 2012; Nain et al., 2015) or other tissue such as liver and brain (Nain et al., 2015).

Toour knowledge, there is no data available about the effects of CAMC, as a rich source of n-3 PUFA, on the plasma lipid status and fatty acid profile of lymphoid tissue in broiler chicks. Therefore, the aim of this study was to determine the effect of camelina cakes on performance, plasma lipid profile and lymphoid tissue fatty acid profile in broiler chicks.

\section{MATERIAL AND METHODS}

The study was performed at the experimental unit of the National Research-Development Institute for Animal Biology and Nutrition (Balotesti, Romania) based on a protocol approved by the Ethical Committee of the institute, in accordance with the EU Directive 2010/63/EU (OJEU, 2010).

\section{Broilers, experimental diets, and sampling}

Six hundred 3-week-old mixed-sex Cobb 500 broilers $(883.26 \pm 15.04 \mathrm{~g})$ were used in a 20 -day feeding trial (finisher phase, 23 to 42 days) conducted in a controlled experimental house. Birds were randomly allotted to 2 dietary groups, with 4 replicates of 75 broilers each and were raised in wood shaving-floor pens. Each pen was equipped with manual feeders and nipple drinker lines. A lighting program of $23 \mathrm{hL}: 1 \mathrm{hD}$ was used for the experimental period. The birds had ad libitum access to feed and water.

The broilers were fed with a control diet based on a corn-soybean meal-canola meal (C) and an experimental diet containing $80 \mathrm{~g} / \mathrm{kg}$ camelina cakes (CAMC) that replaced the canola meal from $C$ diet. The finisher diets (Table 1) were isocaloric, isonitrogenous and formulated to meet the nutrient requirements of broiler hybrid (Cobb-Vantress,2015). The camelina cake used in this study was provided from the local commercial oil processing plant and was obtained by cold-pressing oil extraction method. The chemical composition of CAMC was $93.5 \%$ dry matter, $30.4 \%$ $\mathrm{CP}, 22.5 \%$ crude fat, $8.8 \%$ crude fibre, $7.4 \%$ ash, $0.5 \%$ calcium, $0.75 \%$ phosphorus, and $12.76 \mathrm{MJ} /$ $\mathrm{kg}$ metabolisable energy. The protein of CAMC had a higher content of essential amino acids such a sarginine $(2.85 \%)$, lysine $(1.54 \%)$, threonine $(1.1 \%)$, methionine $(0.83 \%)$ and cysteine $(0.71 \%)$.

The ingredients and analyzed composition of the experimental diets are given in Table 1.

Body weight (BW) and feed intake (FI) were measured and body weight gain (BWG), feed conversion ratio (FCR) was calculated from 23 to 42 days. Mortality rates were recorded daily, to make corrections in calculating $\mathrm{Fl}$ and FCR during the experimental period.

At slaughter age (42 days), twelve birds per treatment (six male and six female) were randomly allocated for blood sampling and immune organs evaluation over a 12-h feed withdrawal period.

Blood samples (4 $\mathrm{ml}$ ) were collected from wing vein in heparinized tubes, stored on ice and immediately processed. After blood sampling broilers were killed by cervical dislocation and bleeding. Carcasses were manually eviscerated and spleen, thymus and bursa of Fabricius were aseptically removed. Lymphoid organs were weighed and stored at $-20^{\circ} \mathrm{C}$ until fatty acid analyses; their relative weights were calculated as the percent of live BW at slaughter.

\section{Chemical and biochemical analysis}

The chemical composition of the ingredients and the diets samples were analysed based on standard procedures (OJEU, 2009), in duplicate for: dry matter (SR ISO 6496:2001), crude protein (SR EN ISO 5983-2:2009 AOAC 2001.11), crude fat (SR ISO 6492:2001), crude fibre (SR EN ISO 6865:2002), 
Table 1 - Ingredients and analyzed composition of diets.

\begin{tabular}{|c|c|c|}
\hline \multirow[t]{2}{*}{ Ingredients, g/kg, as-fed basis } & \multicolumn{2}{|c|}{ Finisher phase, 23 to 42 days } \\
\hline & $\mathrm{C}^{1}$ & CAMC $^{2}$ \\
\hline Corn & 613.5 & 617.8 \\
\hline Soybean meal & 178.0 & 188.3 \\
\hline Camelina cake & - & 80.0 \\
\hline Canola meal & 80.0 & - \\
\hline Corn gluten meal & 25.0 & 25.0 \\
\hline Vegetable oil & 54.0 & 39.0 \\
\hline Monocalcium phosphate & 16.7 & 16.5 \\
\hline Calcium carbonate & 14.6 & 14.9 \\
\hline Salt & 3.0 & 3.0 \\
\hline Vitamin-mineral premix ${ }^{3}$ & 10.0 & 10.0 \\
\hline DL-Methionine & 1.7 & 1.7 \\
\hline L-Lysine $\mathrm{HCl}$ & 2.9 & 3.2 \\
\hline Choline $\mathrm{HCl}$ & 0.6 & 0.6 \\
\hline \multicolumn{3}{|l|}{ Analyzed composition } \\
\hline Crude protein & 181.1 & 181.0 \\
\hline Lysine & 10.56 & 10.54 \\
\hline Methionine+cystine & 8.18 & 8.16 \\
\hline Calcium & 8.8 & 8.9 \\
\hline Phosphorus & 8.2 & 8.3 \\
\hline Crude fibre & 37.8 & 38.0 \\
\hline Crude fat & 62.8 & 63.8 \\
\hline Metabolisable energy $(\mathrm{MJ} / \mathrm{kg})^{4}$ & 13.39 & 13.39 \\
\hline
\end{tabular}

${ }^{1} \mathrm{C}$ - Control; ${ }^{2}$ CAMC - Camelina cake; ${ }^{3}$ Supplied per kg diet: retinyl acetate, $2.90 \mathrm{mg}$; cholecalciferol, $0.12 \mathrm{mg}$; DL- $\alpha$-tocopheryl acetate, $50 \mathrm{mg}$; menadione sodium bisulphite, $3 \mathrm{mg}$; thiamine mononitrate, $2 \mathrm{mg}$; riboflavin, $8 \mathrm{mg}$; pyridoxine- $\mathrm{HCl}, 3 \mathrm{mg}$; cyanocobalamin, $0.015 \mathrm{mg}$; Ca-panthotenate, $12 \mathrm{mg}$; niacin, $50 \mathrm{mg}$; folic acid, $1.5 \mathrm{mg}$; Mn, $100 \mathrm{mg} ; \mathrm{Zn}, 100 \mathrm{mg} ; \mathrm{Fe}, 40 \mathrm{mg} ; \mathrm{Cu}, 15 \mathrm{mg} ; \mathrm{l}, 1.0 \mathrm{mg} ; \mathrm{Se}, 0.30 \mathrm{mg} ; \mathrm{Co}, 0.25 \mathrm{mg}$. ${ }^{4}$ based on regression equations(NRC, 1994).

crude ash (SR EN ISO 2171:2010), calcium (SR ISO 6490-2:1983), phosphorus (spectrophotometry method) and amino acid profile (HPLC-high performance liquid chromatography). Metabolisable energy (ME) content was calculated based on the energy content of feed ingredients using regression equations (NRC, 1994).

Fatty acid profile of ingredients, diets and immune tissue samples were determined by the gas chromatography method (SR CEN ISO/TS 177642:2008) using Perkin Elmer500 chromatograph. The method was previously described by Hăbeanu et al. (2014) and consisted in transforming the sample fatty acids in methyl esters, followed by the separation of the components in the chromatography column, their identification by comparison with standard chromatograms and the quantitative determination of the fatty acids (expressed as \% total fatty acid methyl esters-FAME).
Blood samples were centrifuged at 2,700 rpm for 10 min at $4^{\circ} \mathrm{C}$, then separated plasma was transferred to Eppendorf tube and stored at $-20^{\circ} \mathrm{C}$ until analyses. Plasma lipid profile (glucose, Glu; total cholesterol, TC; high-density lipoprotein cholesterol, HDL-C; lowdensity lipoprotein cholesterol, LDL-C; triglycerides, TG) were determined on chemistry analyzer (BS130, Shenzhen Mindray Bio-Medical Electronics Co., China), using Accent-200 MG kits (Cormay, Wiosenna, Poland). Very low-density lipoproteincholesterol (VLDL-C) values were calculated by the formula: VLDL-C = Triglycerides divided by 5 (Tietz, 1996).

\section{Statistical analysis}

For performance parameters, replication was considered as the experimental unit for the statistical analysis and other results were analyzed with every broiler as a replicate. Data were analyzed with a oneway ANOVA procedure of SPSS version 20.0 software (IBM SPSS Inc., 2014). The results were expressed as means with standard error of the mean (SEM) and value for fatty acids are expressed as the percentage of total fatty acid ester methyl (\% of total FAME). Differences between means were considered statistically different at $p<0.05$.

\section{RESULTS AND DISCUSSION}

\section{Fatty acid profile of camelina cake and diets.}

Table 2 shows that the fatty acid profile of camelina cake used in our study and obtained by cold-pressing oil extraction method, is a rich source of $\alpha$-linolenic acid (ALA, 29.47\%), linoleic acid (LA, $21.09 \%)$, and oleic acid (17.69\%).Similar results have been reported previously by Nain et al. (2015) and Juodka et al. (2018). The fatty acid composition of diets showed that the inclusion of $80 \mathrm{~g} / \mathrm{kg}$ CAMC increased the ALA content (2.87-fold) and resulted in a 3.89-fold decrease of the LA: ALA ratio, compared with the classical diet. It is stated that ALA is the precursor of long-chain n-3 PUFA such as eicosapentaenoic acid (EPA) and docosahexaenoic acid (DHA), which have received considerable attention as functional nutrients for their various health-promoting effects (Rymer \& Givens, 2005; Schmitz \& Ecker, 2008). Thus, to obtain an efficient conversion of ALA into EPA and DHA it is important to assure an adequate dietary LA: ALA ratio (Griffin, 2008). 
Table 2 - Fatty acid profile (\% of total FAME) of camelina cake and experimental diets.

\begin{tabular}{|c|c|c|c|}
\hline \multirow[t]{2}{*}{ Fatty acid ( $\%$ of total FAME) ${ }^{*}$} & \multirow[t]{2}{*}{ Camelina cake } & \multicolumn{2}{|c|}{$\begin{array}{l}\text { Finisher phase, } \\
23 \text { to } 42 \text { days }\end{array}$} \\
\hline & & C & CAMC \\
\hline C14:0 (myristic) & 0.15 & 0.09 & 0.10 \\
\hline C16:0 (palmitic) & 7.43 & 8.76 & 8.77 \\
\hline C16:1 (palmitoleic) & 0.24 & 0.21 & 0.24 \\
\hline C18:0 (stearic) & 2.01 & 2.87 & 2.38 \\
\hline C18:1 cis-9 (oleic) & 17.69 & 24.80 & 19.92 \\
\hline C18:2n-6 (linoleic, LA) & 21.09 & 61.31 & 45.37 \\
\hline C18:3n-3 (alpha-linolenic, ALA) & 29.47 & 2.24 & 6.44 \\
\hline$\Sigma S F A$ & 9.59 & 11.72 & 11.25 \\
\hline$\Sigma$ MUFA & 17.93 & 25.01 & 20.16 \\
\hline LA:ALA & 0.72 & 27.37 & 7.04 \\
\hline
\end{tabular}

C - Control; CAMC - Camelina cake; ${ }^{*}$ FAME- fatty acids methyl esters; $\Sigma$ SFA $=$ C14:0 + C16:0 + C18:0; IMUFA = C16:1 + C18:1 cis-9.

\section{Performance parameters}

The effects of dietary CAMC on production parameters and lymphoid tissue weights of broiler chicken are shown in Table 3. There was no significant difference $(p>0.05)$ in BW, WG, FI and FCR between the dietary treatments at the end of the finisher phase (42 days). Similarly, previous studies feeding diets up to $10 \%$ camelina meal reported no significant differences in turkey broiler performance (Frame et al., 2007) or in broiler final body weight, feed efficiency and carcass weight at 42 days of age (Aziza et al., 2010). Other studies also indicated that the addition of camelina oil in broiler chicken's diets had no significant effects on performance and carcass quality parameters (Pietras \&
Orczewska-Dudek, 2013; Jaskiewicz et al., 2014). On the contrary, Thacker \& Widyaratne (2012) stated that dietary camelina meal inclusion up to15\% decreased BW gain and impaired the feed conversion of broiler chickens. Pekel et al. (2015) fed broilers with 10 and $20 \%$ camelina meal from 21-28 days of age and reported detrimental effects on performance and attributed this negative impact to the presence of glucosinolates in camelina by-product.

In our study, the relative weights of lymphoidorgans at 42 days (Table 3 ) were not affected ( $p>0.05$ ) by the CAMC addition in the diet, except the weight of the bursa of Fabricius that significantly decreased $(p=0.039)$. Previous studies have shown that lymphoid tissue development can reflect the immune status (Grasman, 2002; Smith \& Hunt, 2004; Akter et al., 2006). Wang et al. (2000) reported that feeding laying hens with diets rich in n-3 PUFA stimulates the growth of immune tissue (thymus, spleen, and bursa) up to 4 weeks of age. The authors suggested that after 4 weeks of age the immune tissue weights began to decrease, and the bursa degenerated between the $4^{\text {th }}$ and the $8^{\text {th }}$ weeks of age. Al-Khalifa et al. (2012) have shown that feeding n-3 PUFA rich diets (30, 50 and 60 $\mathrm{g} / \mathrm{kg}$ fish oil) had no effect on the relative weight of the spleen, but significantly higher the thymus weights in broilers fed diet with $50 \mathrm{~g} / \mathrm{kg}$ fish oil and significantly lower the bursa weights in broilers fed diets containing 50 and $60 \mathrm{~g} / \mathrm{kg}$ fish oil than those of broilers fed the control diet or $30 \mathrm{~g} / \mathrm{kg}$ fish oil.

Table 3 - Effect of dietary camelina cake on broilergrowth performance, lymphoid organ weights and abdominal fat weight.

\begin{tabular}{|c|c|c|c|c|}
\hline \multirow[t]{2}{*}{ Item } & \multicolumn{2}{|c|}{ Diets } & \multirow[t]{2}{*}{ SEM } & \multirow[t]{2}{*}{$p$-value } \\
\hline & C & CAMC & & \\
\hline \multicolumn{5}{|l|}{ Finisher phase, 23 to 42 days $^{1}$} \\
\hline Initial body weight(g/broiler) & 890.02 & 876.50 & 5.31 & 0.228 \\
\hline Final body weight(g/broiler) & 2375.82 & 2340.13 & 38.01 & 0.674 \\
\hline Weight gain (g/broiler) & 1485.80 & 1463.63 & 40.03 & 0.805 \\
\hline Feed intake (g/broiler) & 2657.50 & 2640.00 & 14.12 & 0.588 \\
\hline Feed conversion ratio(g feed:g gain) & 1.79 & 1.80 & 0.04 & 0.867 \\
\hline \multicolumn{5}{|l|}{ Lymphoid tissue, $\%$ of BW ${ }^{2}$} \\
\hline Spleen & 0.12 & 0.10 & 0.002 & 0.723 \\
\hline Thymus & 0.20 & 0.17 & 0.01 & 0.240 \\
\hline Bursa of Fabricius & $0.18^{\mathrm{a}}$ & $0.13^{b}$ & 0.004 & 0.039 \\
\hline Abdominal fat, $\%$ of $B W^{2}$ & 1.90 & 1.86 & 0.07 & 0.691 \\
\hline
\end{tabular}

C - Control; CAMC - Camelina cake; SEM - standard error of the mean;

${ }^{1}$ Means of 4 replicates per treatment ( $n=75$ broilers from each replicate), at 42 days of age. ${ }^{2}$ Means of 12 broilers per treatment, at 42 days of age.

${ }^{a b}$ Means within a row with no common superscript are significantly different $(p<0.05)$.

\section{Plasma lipid status}

The results indicated that dietary CAMC affects the plasma lipid profile (Table 4). Thus, glucose concentration was significantly decreased $(4.37 \% ; p=0.037)$, total cholesterol and its fractions HDL-C and LDL-C were also decreasedby $12.30 \% \quad(p=0.013), 9.21 \% \quad(p=0.019)$ and $29.45 \%(p=0.002)$, respectively. The plasma LDL-C was negatively correlated with the ALA fatty acid content 
of the diet $(r=-0.58, p=0.002)$. The values of very lowdensity lipoprotein cholesterol (VLDL-C) and triglycerides were lower compared to the $C$ group with no significant difference $(p>0.05)$. It is considered that VLDL-C concentrations are good indicators of fat deposition in the bird (Whitehead \& Griffin, 1984; Grunder et al. 1987). This confirms the results of our study regarding the abdominal fat content, expressed as \% of BW at slaughter, which was lower (1.86\% vs. $1.90 \%$; $p>0.05$; Table 3 ) compared to the $\mathrm{C}$ group as the effect of CAMC addition.
Our results are in line with what was previously reported by Taranu et al. (2014) who found that feeding camelina cake in finishing pigs improves the blood biochemistry profile by decreasing plasma glucose and increasing plasma antioxidant capacity. Fébel et al. (2008) have shown that feeding broilers with different sources rich in PUFA decrease plasma total cholesterol, and the decrease could be attributed to a suppression of hepatic cholesterol production by the high PUFA levels.

Table 4 - Effect of dietary camelina cake on the plasma lipid profile of broilers at 42 days.

\begin{tabular}{lcccc}
\hline Parameter $(\mathrm{mg} / \mathrm{dl})$ & \multicolumn{2}{c}{ Siets } & \multirow{2}{*}{ SEM } & \\
\cline { 2 - 3 } & $\mathrm{C}$ & CAMC & \\
\hline Glucose & $271.06^{\mathrm{a}}$ & $259.22^{\mathrm{b}}$ & 2.87 & 0.037 \\
Total Cholesterol & $108.18^{\mathrm{a}}$ & $94.87^{\mathrm{b}}$ & 2.78 & 0.013 \\
HDL-Cholesterol & $72.33^{\mathrm{a}}$ & $65.67^{\mathrm{b}}$ & 1.75 & 0.019 \\
LDL-Cholesterol & $26.21^{\mathrm{a}}$ & $18.49^{\mathrm{b}}$ & 1.36 & 0.002 \\
VLDL-Cholesterol & 9.64 & 8.72 & 0.33 & 0.170 \\
Triglycerides & 48.19 & 43.58 & 0.175 \\
\hline
\end{tabular}

C - Control; CAMC - Camelina cake; SEM - standard error of the mean;

VLDL-Cholesterol=Triglycerides divided by 5 (Tietz, 1996).

Means of 12 broilers per treatment, at 42 days of age.

abMeans within a row with no common superscript are significantly different $(p<0.05)$.

\section{Lymphoid tissue fatty acid profile}

The effects of dietary CAMC on the fatty acid profile of the spleen, the thymus, and the bursa of Fabricius in broiler chicks are presented in Table 5. As response to feeding CAMC in broilers the total saturated fatty acids (SFA) was increased $(p=0.029)$ by 1.08 -fold in the thymus and 1.06-fold in the bursa, while the predominant SFA, palmitic acid (C16:0) increased in all immune tissues (1.06-fold in the bursa, 1.07-fold in the spleen and 1.09-fold in the thymus; $p=0.002$ ). The content of palmitoleic acid (C16:1) increased in all lymphoid tissues (1.33-fold in the spleen and in the bursa, 1.40 -fold in the thymus; $p<0.0001$ ). However, the content of oleic acid (C18:1cis-9) decreased in the thymus and in the bursa (1.11-fold; $p=0.009$ ). Villaverde et al. (2006) reported that feeding broilers with rich PUFA diets could decrease the oleic acid due to an inhibition effect of increased dietary n-3 PUFAs on the $\Delta$-desaturase enzyme, lowering de novo synthesis of monounsaturated fatty acids (MUFAs).

Our results have shown that the MUFAs concentration significantly decreased $(p<0.0001)$ in the thymus (1.04-fold) and in the bursa (1.07-fold) tissues as an effect of dietary CAMC addition. It is stated that the increase of PUFAs concentration led to decreases in MUFAs in tissues due to their inhibitory role of the desaturase enzyme needed for synthesis of MUFAs (Lefevre et al., 2001).

As expected, the composition of the CAMC diet, especially the essential FA content is reflected in the PUFA profile of lymphoid organs. The LA (C18:2n-6) content as predominant $n-6$ PUFA significantly decreased in all tissues $(1.58$-fold in the bursa, 1.61 -fold in the thymus and 1.30 -fold in the spleen; $p<0.0001$ ) of broilers fed CAMC diet and the total PUFAs content also decreased $(p<0.0001)$ compared with $C$ diet. However, the increase in ALA (C18:3n-3) content (4.33-fold in the bursa, 4.29-fold in the thymus and 6.06-fold in the spleen; $p<0.0001)$ led to an increase of the total $n-3$ PUFAs in all the immune tissues (4.0-fold in the spleen, 3.24-fold in the thymus and 3.29-fold in the bursa; $p<0.0001)$ as effect of feeding CAMC diet.

Eicosadienoic acid (C20:2n-6) level was higher $(p<0.0001)$ in all tissues $(2.19$-fold in the bursa, 3.62fold in the spleen and 4.58-fold in the thymus) and eicosatrienoic acid (C20:3n-3) was lower (1.44-fold in the thymus, 1.63 -fold in the spleen and 2.58 -fold in the bursa; $p=0.003$ ) affected by dietary treatments. Arachidonic acid (AA; C20:4n-6) concentration signifi-cantly decreases ( $p=0.002$ ) by 1.32 -fold in the thymus, 1.47-fold in the bursa and 1.78-fold in the the spleen. 
Table 5 - Effect of dietary camelina cake on immune tissue fatty acid profile of broilers.

\begin{tabular}{|c|c|c|c|c|c|c|c|c|c|}
\hline \multirow{2}{*}{$\begin{array}{l}\text { Tissue } \\
\text { Diets } \\
\end{array}$} & \multicolumn{2}{|c|}{ Spleen } & \multicolumn{2}{|c|}{ Thymus } & \multicolumn{2}{|c|}{ Bursa Fabricius } & \multirow[t]{2}{*}{ SEM } & \multicolumn{2}{|c|}{$p$-value } \\
\hline & C & CAMC & $\mathrm{C}$ & CAMC & $\mathrm{C}$ & CAMC & & Diet & Tissue \\
\hline \multicolumn{10}{|c|}{ Fatty acids (\% of total FAME) } \\
\hline C14:0 & 0.65 & 0.66 & 0.70 & 0.79 & 0.68 & 0.86 & 0.01 & 0.103 & 0.207 \\
\hline C16:0 & $21.04^{b, z}$ & $22.47^{\mathrm{a}, \mathrm{z}}$ & $23.80^{\mathrm{b}, \mathrm{x}}$ & $25.99^{a, x}$ & $21.39^{b, y}$ & $22.53^{a, y}$ & 0.31 & 0.002 & $<0.0001$ \\
\hline C16:1 & $4.07^{b, y}$ & $5.40^{a, y}$ & $4.28^{b, x}$ & $5.99^{a, x}$ & $3.41^{\mathrm{b}, \mathrm{z}}$ & $4.53^{a, z}$ & 0.16 & $<0.0001$ & 0.001 \\
\hline C18:0 & 8.75 & 7.46 & 6.62 & 6.69 & 8.43 & 9.00 & 0.20 & 0.532 & 0.158 \\
\hline C18:1cis-9 & $32.93^{a}$ & $31.50^{b}$ & $35.14^{\mathrm{a}}$ & $31.68^{b}$ & $35.34^{a}$ & $31.80^{b}$ & 0.31 & 0.009 & 0.342 \\
\hline C18:2n-6 & $24.29^{a}$ & $18.6^{b}$ & $26.81^{a}$ & $16.64^{b}$ & $26.62^{a}$ & $16.87^{b}$ & 0.75 & $<0.0001$ & 0.972 \\
\hline C 18:3n-3 & $0.86^{b, x}$ & $5.22^{a, x}$ & $0.82^{b, z}$ & $3.52^{a, z}$ & $0.99^{b, y}$ & $4.29^{a, y}$ & 0.01 & $<0.0001$ & 0.044 \\
\hline$C 20: 2 n-6$ & $0.40^{\mathrm{b}}$ & $1.45^{\mathrm{a}}$ & $0.43^{b}$ & $1.97^{\mathrm{a}}$ & $0.57^{b}$ & $1.25^{\mathrm{a}}$ & 0.08 & $<0.0001$ & 0.054 \\
\hline$C 20: 3 n-3$ & $0.62^{a, x}$ & $0.38^{b, x}$ & $0.36^{a, z}$ & $0.25^{b, z}$ & $0.49^{a, y}$ & $0.19^{b, y}$ & 0.04 & 0.003 & 0.013 \\
\hline$C 20: 4 n-6$ & $3.76^{a, x}$ & $2.11^{b, x}$ & $2.71^{a, y}$ & $2.05^{b, y}$ & $1.16^{a, z}$ & $0.79^{b, z}$ & 0.17 & 0.002 & $<0.0001$ \\
\hline$C 20: 5 n-3$ & $0.08^{b}$ & $0.55^{a}$ & $0.13^{b}$ & $0.47^{a}$ & $0.10^{\mathrm{b}}$ & $0.48^{a}$ & 0.04 & $<0.0001$ & 0.791 \\
\hline$\Sigma$ SFA & $30.52^{\mathrm{a}}$ & $30.78^{a}$ & $31.44^{b}$ & $33.80^{a}$ & $30.60^{b}$ & $32.45^{a}$ & 0.35 & 0.029 & 0.059 \\
\hline$\Sigma$ MUFA & $37.97^{a}$ & $37.68^{a}$ & $40.02^{a}$ & $38.35^{b}$ & $39.38^{a}$ & $36.85^{b}$ & 0.41 & $<0.0001$ & 0.328 \\
\hline$\Sigma$ PUFA & $30.01^{a}$ & $28.33^{b}$ & $31.26^{\mathrm{a}}$ & $24.90^{b}$ & $29.93^{a}$ & $23.87^{b}$ & 0.67 & $<0.0001$ & 0.175 \\
\hline$\Sigma$ n-6 PUFA & $28.48^{a}$ & $22.18^{b}$ & $29.95^{a}$ & $20.66^{b}$ & $28.35^{a}$ & $18.91^{b}$ & 0.72 & $<0.0001$ & 0.419 \\
\hline In-3 PUFA & $1.56^{b, x}$ & $6.15^{a, x}$ & $1.31^{\mathrm{b}, \mathrm{z}}$ & $4.24^{\mathrm{a}, \mathrm{z}}$ & $1.58^{\mathrm{b}, \mathrm{y}}$ & $4.96^{a, y}$ & 0.26 & $<0.0001$ & 0.017 \\
\hline$\Sigma$ LCn-3 PUFA & $0.70^{\mathrm{b}}$ & $0.93^{a}$ & $0.49^{b}$ & $0.72^{\mathrm{a}}$ & $0.59^{a}$ & $0.67^{a}$ & 0.05 & 0.047 & 0.093 \\
\hline$\Sigma$ n-6: $\Sigma$ n-3 ratio & $18.25^{a}$ & $3.61^{b}$ & $22.86^{\mathrm{a}}$ & $4.87^{b}$ & $17.94^{\mathrm{a}}$ & $3.81^{\mathrm{b}}$ & 1.28 & $<0.0001$ & 0.144 \\
\hline
\end{tabular}

C - Control; CAMC - Camelina cake; SEM - standard error of the mean; 'FAME- fatty acids methyl esters.

Means of 12 broilers per treatment, at 42 days of age.

${ }^{\text {ab }}$ Means within rows with no common superscript are significantly different $(p<0.05)$ for diet effect.

${ }^{x y z}$ Means within rows with no common superscript are significantly different $(p<0.05)$ for tissue effect.

$\Sigma$ SFA $=$ C14:0 + C15:0 + C16:0 + C17:0 + C18:0; $\Sigma$ MUFA $=$ C15:1 + C16:1 + C17:1 + C18:1 cis-9; $\Sigma$ PUFA = C18:2n-6 + C18:3n-3 + C20:2n-6 + C20:3n-3 + C20:4n-6 + C20:5n-3; $\Sigma L C n-3$ PUFA $=C 20: 3 n-3+C 20: 5 n-3$.

Eicosapentaenoic acid (EPA; C20:5n-3) content increased $(p<0.0001)$ in the immune organs of broilers fed CAMC diet compared with $C(3.62$-fold in the thymus, 4.8-fold in the bursa and 6.88-fold in the spleen). It was noticed that the spleen, that is the major immune organ, contained more EPA than other immune tissues and this fact could be related with a higher capacity for eicosanoid production, which is predominated by arachidonic acid (Al-Khalifa et al., 2012). The AA and EPA are metabolites of LA and ALA (Schmitz \& Ecker, 2008) and usually AA decrease when n-3 PUFA increases (Komprda et al. 2005).

The sum of $n-6$ PUFAs decreased $(p<0.0001)$ in the bursa (1.51-fold), thymus (1.45-fold), and spleen (1.28fold) compared with the $C$ diet. These results are in line with previous studies that stated that the LA and ALA compete for the same desaturase enzymes (Crespo \& Esteve-Garcia, 2001; Lopez-Ferrer et al., 2001).

As results of dietary CAMC inclusion, the $n-6: n-3$ ratio decreased in all immune tissues $(4.87 \%$ in the thymus, $3.81 \%$ in the bursa and $3.61 \%$ in the spleen; $p<0.0001)$ compared with $C$ diet. It is stated that a lower ratio of n-6:n-3 PUFAs in poultry diets decreases the competition of ALA with LA for enzymes involved in bioconversion to long-chain (LC) n-3 PUFAs, resulting in increased tissue content (Riediger et al., 2009; Nain et al., 2012). In our study, the higher deposition of sum LCn-3 PUFAs was noticed in all immune tissue, especially in the thymus and the spleen $(p=0.047)$ as an effect of dietary CAMC addition.

Regarding the tissue effects (Table 5) at the level of individual FA the significantly higher deposition was found for palmitic acid (C16:0)thymus $>$ bursa $>$ spleen $(p<0.0001)$, palmitoleic acid (C16:1) thymus $>$ spleen $>$ bursa $(p<0.001)$, ALA $(C 18: 3 n-3)$ spleen $>$ bursa $>$ thymus $(p=0.044)$, eicosatrienoic acid $(C 20: 3 n-3)$ spleen >bursa >thymus $(p=0.013)$, AA $(C 20: 4 n-6)$ spleen $>$ thymus $>$ bursa $(p<0.0001)$. Total $n-3$ PUFA amount was significantly higher in spleen >bursa $>$ thymus ( $p=0.017)$. Poureslami et al. (2010) have also reported differences in the tissue-specific distribution of $n-3$ PUFAs in broilers.

To our knowledge, there are no published reports evaluating the effect of dietary camelinacakes on the lymphoid tissue fatty acid profile. However, Al-Khalifa et al. (2012) studied the effect of feeding increasing levels of fish oil $(30,50$ and $60 \mathrm{~g} / \mathrm{kg})$ on immune function in Ross 308 broilers from 21 to 47days. These authors reported no significant effect of fish oil enriched diets on the proportions of ALA in the bursa; a significant 
decrease in the total amount of n-6 PUFA, AA, and the $n-6: n-3$ ratio in the bursa, spleen and thymus concomitant with a significant increase of n-3 PUFA in immune tissue and blood leukocytes compared with the control diet. Recently, Nain et al. (2015) investigated the effects of different levels of dietary camelina cake $(8,16$ and $24 \%)$ on lipid deposition in different tissue (brain, liver, breast, and thigh) in Ross 308 broilers for 42days. These authors observed that the deposition of different n-3 PUFA types in tissue was variable: the predominantn-3 PUFA in the liver and the brain tissue was docosahexaenoic acid (48 and $88 \%$, respectively), whereas in the breast and the thigh tissue was ALA ( 65 and $86 \%$, respectively). The accumulation efficiency of essential fatty acids (LA and ALA) in the breast and the thight issue, along with the deposition of n-3 PUFAs, showed a variable affinity of each fatty acid for the different tissue types (Nain et al., 2015).

In conclusion, the results of the present study indicate that feeding $80 \mathrm{~g} / \mathrm{kg}$ camelina cake in broiler chicks, as a rich source of n-3 PUFA, had no negative impact on productivity, beneficially alter the plasma lipid status and fatty acids profile of lymphoid tissue.

\section{ACKNOWLEDGMENTS}

This study was funded by the Romanian Ministry of Research and Innovation through Subprogram 1.2. Institutional Performance, Program 1. Developing National R\&D, National Research and Development and Innovation, Contract no. 17 PFE/17.10.2018.

\section{REFERENCES}

AkterSH, Khan MZI, Jahn MR, Karim MR, Islam MR. Histomorphological study of the lymphoid tissues of broiler chickens. Bangladesh Journal of Veterinary Medicine 2006;2:87-92.

Al-Khalifa H, Givens DI, Rymer C, Yaqoob P. Effect of n-3 fatty acids on immune function in broiler chickens. Poultry Science 2012;91:74-88.

Aziza AE, Quezada N, Cherian G.Feeding Camelina sativa meal to meattype chickens: Effect on production performance and tissue fatty acid composition. Journal Appliedof Poultry Research 2010;19:157-168.

Batista FD, Harwood NE. The who, how and where of antigen presentation to B cells. Nature Reviews Immunology 2009;9:15-27.

Babu US, Wiesenfeld PL, Raybourne RB, Myers MJ, Gaines D. Effect of dietary fishmeal on the cell-mediated immune response of laying hens. International Journal Poultry Science 2005;4:652-656.

Bhalerao S, Hegde M, Katyare S, Kadam S. Promotion of omega-3 chicken meat production: an Indian perspective. World Poultry Science Journal 2014;70(2):365e74.

Calder PC. n-3 polyunsaturated fatty acids, inflammation, and inflammatory diseases. American Journal of Clinical Nutrition 2006; 83:1505S-1519S.
Cinader B, Clandinin MT, Hosokawa T, Robblee NM. Dietary fat alters the fatty acid composition of lymphocyte membranes and the rate at which suppressor capacity is lost. Immunology Letter 1983;6:331-337.

Cherian G, Campbell A, Parker T. Egg quality and lipid composition of eggs from hens fed Camelina sativa. Journal Applied of Poultry Research 2009;18:143-150.

Cherian G. Camelina sativa in poultry diets: Opportunities and challenges. In: Makkar HPS, editor. Biofuel Co-products as Livestock Feed: Opportunities and Challenges. Rome: FAO; 2012. p.303-310.

Cobb-Vantress.COBB 500 Broiler Performance and Nutrition Supplement. July 2015 .

Crespo N, Esteve-Garcia E. Dietary fatty acid profile modifies abdominal fat deposition in broiler chickens. Poultry Science 2001;80:71-78.

Fébel H, Mézes M, Pálfy T, Hermán A, Gundel J, Lugasi A, Balogh K, Kocsis I, Blázovics A. Effectof the dietary fatty acid pattern on growth, body fat composition and antioxidant parameters in broilers. Journal of Animal Physiology and Animal Nutrition 2008;92:369-376.

Frame DD, Palmer M, Peterson B. Use of Camelina sativa in the diets of young turkeys. Journal Applied of Poultry Research 2007;16:381-386.

Ghamkhar K, Croser J, Aryamanesh N, Campbell M, Konkova N, Francis C. Camelina sativa (L. Crantz) as an alternative oilseed: Molecular and ecogeographic analyses. Genome 2010;3:558-567.

Grasman KA. Assessing immunological function in toxicological studies of avian wildlife. Integrative and Comparative Biology 2002;42:34-42.

Griffin BA. How relevant is the ratio of dietary n- 6 ton-3 polyunsaturated fatty acids to cardiovascular diseaserisk? Evidence from the OPTILIP study. Current Opinion in Lipidology 2008; 19:57-62.

Grunder AA, Chamber JR, Fortin A. Plasma very low-density lipoproteins, abdominal fat, and fatness during rearing in two strains of broiler chickens. Poultry Science 1987;66:471-479.

Hartman S, Taleb SA, Geng T, Gyenai K, Guan X, Smith E. Comparison of plasma uric acid levels in five varieties of the domestic turkey. Poultry Science 2006;85:1791-1794.

Hăbeanu M, Thomas A, Bispo E, Gobert M, Gruffat D, Durand D, Bauchart D. Extruded linseed and rapeseed both influenced the fatty acid composition of total lipids and their polar and neutral fractions in longissimus thoracis and semitendinosus muscles of finishing Normand cows. Meat Science 2014,96: 99-106.

Huang SC, Fritsche KL. Alteration in mouse splenic phospholipid fatty acid composition and lymphoid cell populations by dietary fat. Lipids 1992;27:25-32.

Jaskiewicz T, Sagan A, Puziol. Effect of Camelina sativa oil on the performance, essential fatty acid level in tissues and fat-soluble vitamin content in the liver of broiler chickens. Livestock Science 2014;165:74-79.

Juodka R, Juska R, Juskiene $\mathrm{V}$, Leikus R, Stankeviciene D, Nainiene R. The effect of feeding with hemp and Camelina cakes on the fatty acid profile of duck muscles. Archives Animal Breeding 2018;61:293-303.

Komprda T, Zelenka J, Fajmonova E,Fialova M,Kladroba D.Arachidonic acid and long-chain n-3 polyunsaturated fatty acid contents in meat of selected poultry and fish species in relation to dietary fat sources. Journal of Agricultural and Food Chemistry 2005;53:6804-6812.

Lefevre P,Tripon E, Plumelet C, Douaire M, Diot C. Effects of polyunsaturated fatty acids and clofibrate on chicken stearoyl-CoA desaturase 1 gene expression. Biochemical and Biophysical Research Communications $2001 ; 280: 25-31$

López-Ferrer S, Baucells MD, Barroeta AC, Galobart J, Grashorn MA. n-3 enrichment of chicken meat. 2. Use of precursors of long-chain polyunsaturated fatty acids: Linseed oil. Poultry Science 2001;80:753761. 
NainS, Renema RA, Korver DR, Zuidhof MJ. Characterization of the n-3 polyunsaturated fatty acid enrichment in laying hens fed an extruded flax enrichment source. Poultry Science 2012;91:1720-1732.

Nain S, Oryschak MA, Betti M, Beltranena E. Camelina sativa cake for broilers: Effects of increasing dietary inclusion from 0 to $24 \%$ on tissue fatty acid proportions at 14,28 , and $42 \mathrm{~d}$ of age. Poultry Science 2015:94:1247-1258

National Research Council (NRC). Nutrient Requirements of Poultry. $9^{\text {th }}$ rev ed.The National Academies Press, Washington D.C. 1994. Available from: http://www.nap.edu/openbook.

OJEU (Official Journal of the European Union). Commission Regulation (EC) No. 152/2009 laying down the methods of sampling and analysis for the official control of feed. 2009.

OJEU(Official Journal of the European Union).Directive 2010/63/EU of the European Parliament and of the Council on the Protection of Animals Used for Scientific Purposes. OJEU 20.10.2010, Series L 276, 33-79.

Pekel AY, Kim JI, Chapple C, Adeola O. Nutritional characteristics of camelina meal for 3-week-old broiler chickens. Poultry Science 2015; 94: $371-378$

Pekel Y,Patterson PH, Hulet RM, Acar N, Cravener TL, Dowler DB, Hunter JM. Dietary Camelina meal versus flaxseed with and without supplemental copper for broiler chickens: Live performance and processing yield. Poultry Science 2009;88:2392-2398.

PietrasMP, Orczewska-Dudek S. The effect of dietary Camelina sativa oil on quality of broiler chicken meat. AnnualAnimal Science2013;13(4):869-882

Poureslami R, Rae K, Turchini GM. Effect of diet, sex and age on fatty acid metabolism in broiler chickens: $n-3$ and $n-6$ PUFA. British Journal Nutrition 2010; 104:189-197.

Puthpongsiriporn U, Scheideler SE. Effects of dietaryratio of linoleic to linolenic acid on performance, antibody production, and in vitro lymphocyte proliferation in two strains ofLeghorn pullet chicks. Poultry Science 2005;84:846-857.

Ribeiro T, Lordelo MM, Alves SP, Bessa RJB, Costa P, Lemos JPC, Ferreira LMA, Fontes CMGA, Prates JAM. Direct supplementation of diet is the most efficient way of enriching broiler meat with n-3 long-chain polyunsaturated fatty acids. British Poultry Science 2013;54(6):753765.

Riediger ND, Othman RA, Suh M, Moghadasian MH. A systemic review of the roles of n-3 fatty acids in health and disease. Journal of the American Dietetic Association 2009; 109:668-679.
Ryhanen EL, Perttila S, Tupasela T,Valaja J, Eriksson C, Larkka K. Effect of Camelina sativa expeller cake on performance and meat quality of broilers. Journal of the Science of Food and Agriculture 2007; 87:1489-1494

Rymer C, Givens DI.n-3 fatty acid enrichment of edible tissue of poultry: A review. Lipids 2005;40:121-130.

SchmitzG,Ecker J.The opposing effects of $n-3$ and n-6 fatty acids. Progress Lipid Research2008;47:147-155.

Smith KG, Hunt JL.On the use of spleen mass as a measure of avian immune system. Oecologia 2004;138:28-31.

SPSS. Statistics version 20.0. IBM SPSS; 2011.

Taranu I, Gras M, Pistol GC, Motiu M, Marin DE. Omega-3 PUFA rich Camelina oil by-products improve the systemic metabolism and spleen cell functions in fattening pigs. PLoS ONE2014; 9(10):e110186. doi:10.1371/journal.pone.0110186.

Tietz NW. Fundamentals of clinical chemistry. $4^{\text {th }}$ ed. Philadelphia: W.B. Saunders Company; 1996.

Thacker $\mathrm{P}$, Widyaratne G. Effects of expeller pressed camelina meal and/or canola meal on digestibility, performance and fatty acid composition of broiler chickens fed wheat-soybean meal-based diets. Archives Animal Nutrition 2012; 66:402-15.

Villaverde C, Baucells MD, Cortinas L, Barroeta AC. Effects of dietary concentration and degree of polyunsaturation of dietary fat on endogenous synthesis and deposition of fatty acids in chickens. British Poultry Science2006;47:173-179.

Wall R, Ross RP, Fitzgerald GF, Stanton C. Fatty acids from fish: the antiinflammatory potential of long chain omega 3 fatty acids. Nutrition Reviews 2010;68:280-289.

Wang YW, Field CJ, Sim JS. Dietary polyunsaturated fatty acids alter lymphocyte subset proportion and proliferation, serum immunoglobulin $\mathrm{G}$ concentration, and immune tissue development in chicks. Poultry Science 2000;79:1741-1748.

Whitehead CC, Griffin HD. Development of divergent lines of lean and fat broilers using plasma very low-density lipoprotein concentration as selection criterion: the first three generations. British Poultry Science 1984;25:573-582.

Wood JD,Enser M, Fisher AV, Nute GR, Sheard PR, Richardson RI, Hughes SI. Whittington FM. Fat deposition, fatty acid composition, and meat quality: A review. Meat Science 2008; 78:343-358. 